\title{
Increasing utilization efficiency of continuously stocked Old World bluestem pasture
}

\author{
W.R. TEAGUE, S.L. DOWHOWER, W.E. PINCHAK, D.R. TOLLESON, AND L.J. HUNT
}

Authors are range ecologist, research associate, range nutritionist, research associate, and technician II at the Texas Agricultural Experiment Station, P.O. Box 1658, Vernon, Tex. 76385, respectively.

\begin{abstract}
The objective of this 2 year study was to identify the optimal height to graze Old World bluestem pasture in the Southern Great Plains under continuous stocking during the growing season. We hypothesized that intensely grazing Old World bluestem pasture would increase utilization efficiency by increasing the proportion of live leaf in the pasture, enhance forage quality and animal performance, and animal performance and root biomass would decline if grazing intensity was beyond an optimal level.

Pastures were maintained at 3 levels of standing crop using continuous variable stocking. Stock adjustments were made weekly. A disc meter was used to maintain pasture disc heights of short (35-40 mm), medium ( $41-45 \mathrm{~mm})$, and tall $(46-55 \mathrm{~mm}$ ) levels. Average standing crops of short, medium, and tall pastures were $1,500,1,900$, and $2,400 \mathrm{~kg} \mathrm{~h}^{-1}$, respectively. On the short pasture treatments the proportion of leaf and live stem was higher $(P<0.05)$ and the proportion of dead stem was less $(P<0.05)$ than that on the tall pasture treatments. There were no significant differences $(P>0.05)$ in crude protein of forage between treatments during the vegetative growth phase in spring when forage nitrogen levels were fairly high $(>1.3 \%)$. When the grass began to produce reproductive organs and when forage nitrogen levels were lower $(<1.3 \%)$, forage crude protein was greater in the short pastures $(\mathbf{P}<0.05)$.

Individual animal performance was greater on the tall than on the short pastures $(\mathbf{P}<0.10)$ over all dates. Individual animal performance was greatest when management maximized the proportion of leaf and live stem while minimizing dead stem. Animal performance per hectare was slightly higher on the short and medium height pastures. Both the short and medium height pastures had approximately 70\% the root biomass of the tall pastures $(P \leq \mathbf{0 . 0 1})$ at the end of the trial. These results indicate that intense continuous variable stocking of Old World bluestem increases the utilization efficiency, but increases animal production per hectare only marginally, and reduces root biomass to an extent that production may not be sustained from year to year.
\end{abstract}

Key Words: Bothriochloa ischaemum, continuous variable stocking, forage quality, herbage allowance, "Plains" Old World bluestem, steer performance.

The authors gratefully acknowledge the facilities and livestock made available to them by Dr. Marvin Sharp and the financial support of the E. Paul and Helen Buck Waggoner Foundation, Inc.. They would also like to thank Jeff Estes, Paula Martinez, Chad Sosolik and Jan Worrall for technical support.

Manuscript accepted 1 Jan. 1996.
In conjunction with grazed annual cereal grains, Old World bluestem (Bothriochloa ischaemum L.) pastures are used to enhance production and profitability of range-based beef systems in the Southern Plains of North America (Sims and Dewald 1982, Coyne and Bradford 1985, Dewald et al. 1985). Old World bluestem is easy to establish, drought hardy, resistant to defoliation and produces quality forage in spring and summer, but forage quality in late summer through winter is very low (Eck and Sims 1984; Dewald et al. 1985; Dabo et al. 1987). Rapid growth rates in spring are followed by seed production and a decline in green leaf proportion (Sims et al. 1983; Eck and Sims 1984; Coyne and Bradford 1986). Consequently, unharvested forage is of inferior nutritive value. Diet quality and intake of animals grazing Old World bluestem is particularly sensitive to the proportion and density of green leaf mass and the leaf to stem ratio (Forbes and Coleman 1986).

Pasture management principles based on understanding the basic biology of grass growth and grazing have been developed in areas of the world that are relatively uniform, cool and moist (Murphy 1990). These principles have not been well tested in the more variable and extreme climate of the Southern Great Plains of North America.

The grazing method of choice in the Southem Great Plains has been continuous stocking. Under continuous stocking, the forage plants are exposed to grazing continuously through the growing season. Since pastures are stocked to the least productive period, stocking rates are conservative. This results in overgrazing of some plants and patches and undergrazing of others. The heavily grazed portions become sparse, unproductive and weedy and the ungrazed portions become rank, self-shade, and are less palatable and nutritious. Unless growing conditions are relatively uniform, these problems are very difficult to control (Blaser et al. 1986; Maxwell and Treacher 1986).

Intense grazing that maintains the pasture in a leafy condition can result in greater production efficiency (Johnson and Parsons 1985; Parsons et al. 1988; Murphy 1990). Photosynthetic rates are greater in younger leaf and the respiratory burden and shading of older plant material is avoided. In addition, production is further enhanced through more rapid nutrient cycling. These factors all result in more growth, an extended growing season and greater levels of water-use-efficiency (McNaughton 1979). Harvest efficiency is increased since a greater percentage of leaf is consumed before it dies and different pasture structure provides the grazing animal greater leaf densities and a diet proportionally greater in leaf and nutrients (Grant et al. 1983; Parsons et al. 1983). 
The objective of this study was to identify the optimal height to graze Old World bluestem in the Southern Great Plains to achieve efficient use under continuous stocking. We hypothesize that grazing Old World bluestem pasture intensely will increase the proportion of live leaf and the quality of available forage. High intensity grazing beyond an optimal level is hypothesized to reduce animal productivity, and root biomass compared to pasture grazed less intensively.

\section{Materials and Methods}

The study site is located $5 \mathrm{~km}$ east of Vernon $\left(34^{\circ} 10^{\prime} \mathrm{N}, 100^{\circ}\right.$ $16^{\prime} \mathrm{W}$ ) in north-central Texas. The climate is continental with an average 220 frost-free, growing days. Mean annual precipitation is $550 \mathrm{~mm}$, varying from $490 \mathrm{~mm}$ to $1,000 \mathrm{~mm}$, that is bimodally distributed with peaks in May (102 mm) and September $(81 \mathrm{~mm})$. Annual mean monthly temperature is $17.4^{\circ} \mathrm{C}$ ranging from $36.4^{\circ}$ $\mathrm{C}$ in July to $-2.3^{\circ} \mathrm{C}$ in January. Evaporation averages $1,835 \mathrm{~mm}$ per annum ( $607 \mathrm{~mm}$ pan). Elevation is $390 \mathrm{~m}$ at the research site and slope is $1-3 \%$. Soils are a mix of Bukreek loams (fine-loamy, mixed, thermic typic Paleustoll), Sagerton clay loams (fine, mixed, thermic Typic Argiustoll), and Wichita clay loams (fine, mixed, thermic Typic Paleustalf). Soils are moderately alkaline ( $\mathrm{pH}=7.8-8.5$ ), had no measurable nitrogen, moderate levels of phosphorus (12 ppm), high potassium (290 ppm), high calcium $(4,540 \mathrm{ppm})$, high magnesium (600 ppm), no salinity, and very low sodium $(<10 \mathrm{ppm})$ and sulphur $(<1 \mathrm{ppm})$.

The study was conducted on a 4 year-old, weed-free pasture of WW-Spar, Old World Bluestem Bothriochloa ischaemum (L.) Ken var ischaemum (WW-573). Using continuous, variable stocking, pastures were kept at 3 different heights. Stock numbers were adjusted weekly following pasture height measurement using a pasture disc-meter (Bransby et al. 1977). The target discmeter heights were short ( $35-40 \mathrm{~mm})$, medium ( $41-45 \mathrm{~mm})$, and tall $(46-55 \mathrm{~mm})$. Each treatment had 2 replicates. Pasture replicate sizes ranged from 3.84 ha to 4.17 ha. In 1992 all pastures were fertilized with $112 \mathrm{~kg} \mathrm{ha}^{-1}$ of nitrogen, as urea, in 2 equal dressings prior to expected rainfall in late April and early June. In 1993, only the April fertilizer application ( $56 \mathrm{~kg} \mathrm{ha}^{-1}$ ) was applied since the trial was terminated at the end of July. To remove residual standing crop from the previous season, all pastures were either burned (1992) or mowed (1993) in late winter.

The pastures were stocked with preconditioned stocker steers on 4 May 1992 and 19 May 1993. In 1992, the initial group of steers was marketed in July and replaced with a second group. The number of steers per pasture ranged from 6 to 12 . Animals were allocated to ensure a balance of breed type and body mass within each treatment replication. A test group of 6 animals remained in each replicate pasture at all times. The mass gains of this test group were used to calculate liveweight gain for that treatment replicate. The total gain for each pasture replicate was calculated using the test group liveweight gain ( $\mathrm{kg} / \mathrm{animal} / \mathrm{day})$ multiplied by the total number of animal-days grazed in each replicate. The starting mass of each group of animals used averaged 271 and $266 \mathrm{~kg}$ in 1992, and $274 \mathrm{~kg}$ in 1993. Cattle were weighed at 28-day intervals, were supplied with salt and mineral blocks and received Ralgro ${ }^{1}$ ear implants.

Use of this product does not imply endorsement by the Texas Agricultural Experiment Station.
Rainfall was recorded on-site and temperature was recorded 15 $\mathrm{km} \mathrm{NW}$ at the Vernon airport. Pasture sampling was stratified into 3 zones with 4 randomly placed quadrats in each: (1) East-furthest from water, (2) terraces, and (3) West-nearest to water. Standing crop was estimated and cages were placed when the steers initially entered the pasture and monthly thereafter. One quadrat was randomly located and a paired quadrat was placed on a similar patch of forage. A coin flip determined the quadrat to be harvested for standing crop estimation. The paired plot was caged and clipped the following month for production estimation. Forage production was considered to be the live portion of the standing crop sample collected when cattle entered the pasture, plus the averaged net increase in the 4 cages within each zone, at each subsequent sampling date. Forage was harvested at the soil surface, dried to a constant mass and weighed. Samples were combined by zones within a pasture and subsampled to determine live leaf, dead leaf, live stem and dead stem. Separate sub-samples were analyzed for crude protein (CP) concentration using A.O.A.C. (1990) standards.

To develop the relationship between disc meter $\left(0.25 \mathrm{~m}^{2}\right)$ height and forage standing crop, 50 circular quadrats $\left(0.25 \mathrm{~m}^{2}\right)$ were clipped in July 1992 and regressed against height. In July 1993, the same procedure was followed using 20 quadrats per treatment. Regressions were developed to describe the relations between standing crop and disc meter height. The best $r^{2}$ values using this method were 0.92 for 1992 and 1993. Improved $r^{2}$ values were obtained using a multiple regression model which included disc meter height and the percentages of live leaf, dead leaf, and stem. Using this regression, $r^{2}$ values were $0.93,0.94$, and 0.92 for short, medium, and tall pastures, respectively.

Root biomass was estimated at the end of each growing season with soil cores $(25 \times 900 \mathrm{~mm})$ in the center of 20 randomly located tufts. Coyne and Bradford (1986) found $90 \%$ of root biomass in the top $400 \mathrm{~mm}$ of soil. Soil was washed from roots on a 0.5 mm sieve (Smucker et al. 1982). Roots were dried at $68^{\circ} \mathrm{C}$.

\section{Data Analysis}

Standing crop, dry matter production, plant organ proportion, forage quality, animal performance and root biomass data were analyzed using repeated measures analysis of variance to test for differences in treatment means. The main effects were similar using individual dates or equivalent year periods, so year analyses are presented. Above-ground standing crop, dry matter production, and plant organ proportion data were analyzed by date (months) and year using whole-pasture and zone-per-pasture averages. To analyze pasture zone differences, means per zone were used since terraces made up approximately $10 \%$ of the area of each pasture. Multiple regressions were used to predict standing crop from disc meter height and relate forage attributes to animal production. The intercept in these models was not significant so no-intercept models were used. All analyses were carried out using the SAS statistical package (SAS 1985). Least significant difference tests (Steel and Torrie 1960) were used to separate means.

\section{Results and Discussion}

\section{Climate}

The temperatures in the 1992 growing period were slightly lower than the long-term means but 1993 temperatures were close 

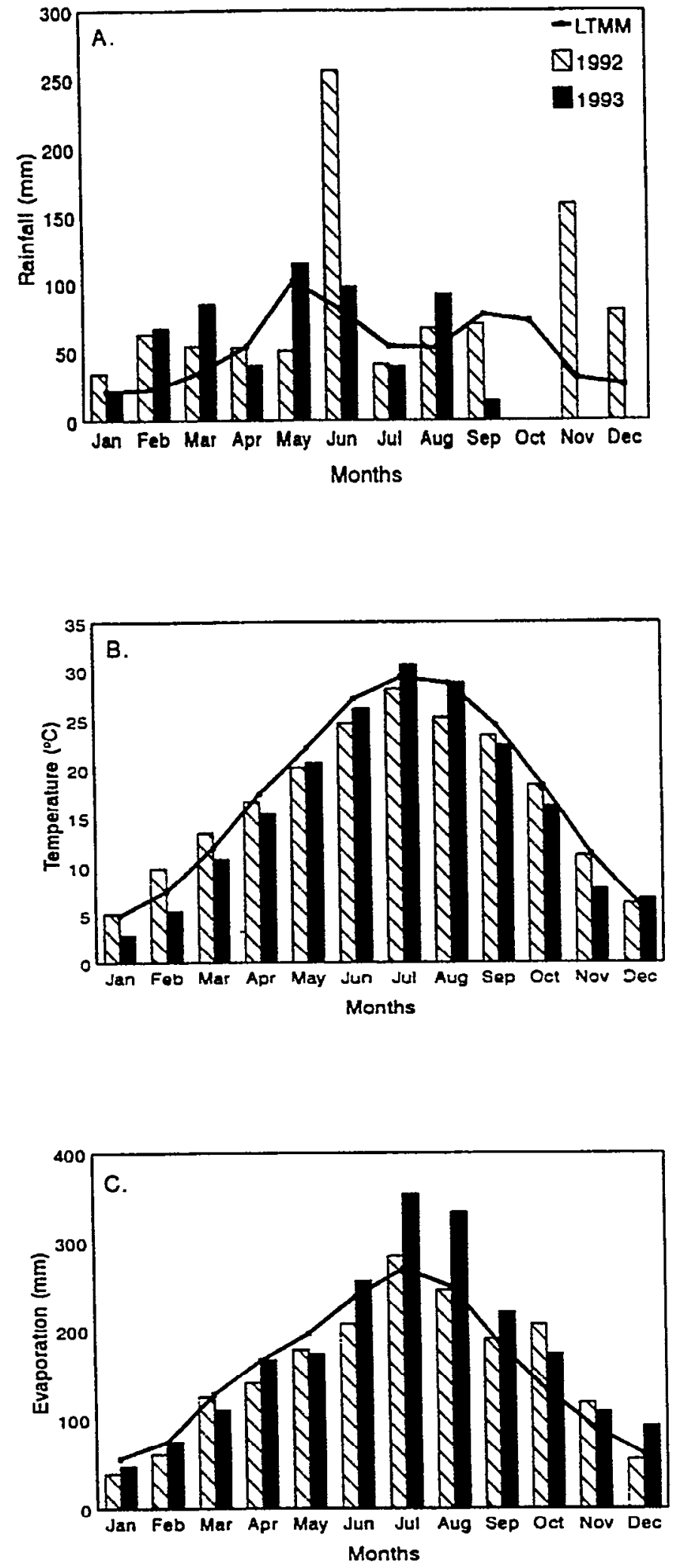

Fig. 1. Mean monthly weather data at the experimental site for 1992 and 1993 compared to long-term mean monthly (LTMM) data. (A) rainfall, (B) temperature, and (C) evaporation. to the long-term means. Evaporation in 1992 was similar to the long-term mean while that in 1993 was somewhat greater, particularly in July and August (Fig 1).

Precipitation prior to growth in May 1992 and 1993 was above average. May was drier than average in 1992 but June was much wetter. In 1993, both May and June were slightly above average. July through September was average in both years.

\section{Standing Crop, Dry Matter Production and Plant Organ Proportions}

Standing crop was significantly different between tall and short treatments $(\mathrm{P} \leq 0.05)$, averaging 2,439 and $1,459 \mathrm{~kg} \mathrm{ha}^{-1}$, respectively (Table 1$)$. Standing crop was less $(P \leq 0.05)$ in 1992 than 1993 (1,468 and 2,378 $\mathrm{kg} \mathrm{ha}^{-1}$, respectively), but live leaf and live stem standing crop did not differ between years. Differing proportions of dead leaf and dead stem in the standing crop $(P \leq 0.05)$ occurred between 1992 and 1993. This was due to the presence of dead leaf and stem aftermath in 1993 following mowing compared to burning in 1992.

Forage production through July did not differ between 1992 and $1993\left(3,707 \mathrm{~kg} \mathrm{ha}^{-1}\right.$ vs $\left.3,167 \mathrm{~kg} \mathrm{ha}^{-1}\right)$ (Table 1). However, it did differ between treatments ( $\mathrm{P} \leq 0.05)$ : (1) $4,520 \mathrm{~kg} \mathrm{ha}^{-1}$ for tall, (2) $3,160 \mathrm{~kg} \mathrm{ha}^{-1}$ for medium, and (3) $2,631 \mathrm{~kg} \mathrm{ha}^{-1}$ for short pastures. However, maximum yield per hectare harvested by grazing does not depend on maximizing the rate of forage production (Grant et al. 1983; Parsons et al. 1983). Harvest efficiency depends primarily on the ratc of tissue loss (Parsons et al. 1988). When whole pastures are considered, grazing intensively increased the proportion of live leaf and stem $(\mathrm{P} \leq 0.05)$ and decreased the proportion of dead stem $(\mathrm{P} \leq 0.05)$ in the pasture (Table 1). Whether this translates into increased animal performance depends on the relative rates of intake of nutrients from pastures maintained at different heights (Parsons et al. 1988).

Within each pasture, the cattle grazed the different zones at varying intensities (Table 2). Greater use was made of the terraces. They had lower standing crops but intermediate dry matter production compared to the other zones (Table 2). Standing crops on the terraces $\left(1,623 \mathrm{~kg} \mathrm{ha}^{-1}\right)$ were less $(\mathrm{P} \leq 0.10)$ than zones closer and further from water (west: $1,841 \mathrm{~kg} \mathrm{ha}^{-1}$ and east: 2,020 $\mathrm{kg} \mathrm{ha}^{-1}$, respectively). But the standing crop on the terraces (1623 $\mathrm{kg} \mathrm{ha}^{-1}$ : Table 2) was more than that of the short treatment pastures $\left(1,459 \mathrm{~kg} \mathrm{ha}^{-1}\right.$ : Table 1$)$. There was less range in standing crop values between the different zones than between the short, medium, and tall pasture treatments (cf. Tables 1 and 2). This is probably why the proportion of plant parts did not differ between the different zones (Table 2).

\section{Forage Crude Protein}

In both years, forage crude protein (CP) declined significantly from relatively high values in May (Table 3). Since these were all hand collected samples, $\mathrm{CP}$ was much lower than might be expected from samples gathered by animals from the same pasture. In 1992, the second application of nitrogen fertilizer in late June CP increased through July and August, before declining to low levels in September and October.

The CP values for May 1993 were significantly lower $(\mathrm{P} \leq$ 0.05 ) than those for May 1992. This is probably due to burning in 1992 compared to mowing in 1993 which resulted in a greater amount of residual dead material in the mowed pastures. Protein concentrations were similar in June of both years $(P>0.05)$. 
Table 1. Average plant organ proportions, standing crop and production in Old World bluestem pasture under tall, medium, and short grazing.

\begin{tabular}{|c|c|c|c|c|c|c|c|c|c|c|}
\hline Treatment & \multicolumn{4}{|c|}{ Plant Organ } & \multicolumn{4}{|c|}{ Standing Crop } & $\begin{array}{l}\text { Standing } \\
\text { Crop }\end{array}$ & $\begin{array}{l}\text { Dry matter } \\
\text { Production }\end{array}$ \\
\hline $\begin{array}{l}\text { Short } \\
\text { Medium } \\
\text { Tall }\end{array}$ & $\begin{array}{c}\% \\
38.5^{a b} \\
42.4^{\mathrm{a}} \\
35.0^{\mathrm{c}}\end{array}$ & $\begin{array}{c}\% \\
22.4 \\
19.2 \\
18.2\end{array}$ & $\begin{array}{c}\% \\
28.0^{\mathrm{b}} \\
28.3^{\mathrm{b}} \\
33.8^{\mathrm{a}}\end{array}$ & $\begin{array}{c}\% \\
10.0^{\mathrm{b}} \\
11.2^{\mathrm{ab}} \\
12.8^{\mathrm{a}}\end{array}$ & $\begin{array}{l}\mathrm{kg} \mathrm{ha}^{-1} \\
541^{\mathrm{b}} \\
756^{\mathrm{ab}} \\
799^{\mathrm{a}}\end{array}$ & $\begin{array}{l}\mathrm{kg} \mathrm{ha}^{-1} \\
353^{\mathrm{b}} \\
396^{\mathrm{ab}} \\
496^{\mathrm{a}}\end{array}$ & $\begin{array}{c}\mathrm{kg} \mathrm{ha}^{-1} \\
415^{\mathrm{b}} \\
515^{\mathrm{b}} \\
802^{\mathrm{a}}\end{array}$ & $\begin{array}{l}\mathrm{kg} \mathrm{ha}^{-1} \\
152^{\mathrm{c}} \\
201^{\mathrm{b}} \\
334^{\mathrm{a}}\end{array}$ & $\begin{array}{l}\mathrm{kg} \mathrm{ha} \mathrm{a}^{-1} \\
1459^{\mathrm{b}} \\
1871^{\mathrm{ab}} \\
2439^{\mathrm{a}}\end{array}$ & $\begin{array}{l}\mathrm{kg} \mathrm{ha}^{-1} \\
2631^{\mathrm{c}} \\
3160^{\mathrm{b}} \\
4520^{\mathrm{a}}\end{array}$ \\
\hline $\begin{array}{l}1992 \\
1993\end{array}$ & $\begin{array}{l}47.5^{\mathrm{A}} \\
29.8^{\mathrm{B}}\end{array}$ & $\begin{array}{l}9.2^{\mathrm{B}} \\
30.6^{\mathrm{A}}\end{array}$ & $\begin{array}{l}33.8 \\
26.3\end{array}$ & $\begin{array}{l}9.3^{B} \\
13.3^{A}\end{array}$ & $\begin{array}{l}674 \\
722\end{array}$ & $\begin{array}{l}132 \\
690\end{array}$ & $\begin{array}{l}520 \\
634\end{array}$ & $\begin{array}{l}137^{\mathrm{B}} \\
321^{\mathrm{A}}\end{array}$ & $\begin{array}{l}1468^{B} \\
2378^{A}\end{array}$ & $\begin{array}{l}3707 \\
3167\end{array}$ \\
\hline
\end{tabular}

Means with the same lower case letter are not significant at $\mathrm{P}<0.05$.

Means with the same upper case letter are not significant at $P<0.05$.

Whenever moisture stress caused plant quiescence, CP dropped significantly. This occurred in July and October 1992, and in July 1993. Coyne and Bradford (1984) observed that extreme summer drought and high temperatures triggered quiescence, which caused a significant decline in forage quality in Old Word bluestem (Forbes and Coleman 1986). Dabo et al. (1987) found digestibility of immature stems to be similar to leaves, but stem digestibility declined more rapidly with advancing maturity than that of leaves, and leaf to stem ratios decreased markedly with age.

\section{Animal Performance}

Individual animal performance was greater on the tall than the short treatment pastures $(\mathrm{P}<0.10)$ over all dates. Gain per hectare was greatest in short, intermediate in medium, and least in tall pastures but these differences were not significant $(\mathrm{P}>0.10)$ (Table 4). The average daily gains (ADG) of 0.64 to $0.75 \mathrm{~kg}^{-19 y^{-1}} \mathrm{com}-$ pare very favorably with results of Volesky et al. (1994) who recorded ADGs of 0.54 to $0.71 \mathrm{~kg}^{-1}{ }^{-1}$ with end of season standing crops of approximately $1,400 \mathrm{~kg} \mathrm{ha}^{-1}$. The gain per hectare of 120 to $129 \mathrm{~kg} \mathrm{ha}^{-1}$ observed in this study, was much lower than

Table 2. Plant organ proportions, standing crop, and production in different zones within Old World bluestem pasture.

\begin{tabular}{|c|c|c|c|c|c|c|c|c|c|c|}
\hline \multirow[b]{2}{*}{$\begin{array}{l}\text { Pasture } \\
\text { Zone }\end{array}$} & \multicolumn{4}{|c|}{ Plant Organ. } & \multicolumn{4}{|c|}{ Standing Crop } & \multirow[b]{2}{*}{$\begin{array}{l}\text { Standing } \\
\text { Crop }\end{array}$} & \multirow[b]{2}{*}{ Production } \\
\hline & $\begin{array}{l}\text { Live } \\
\text { leaf }\end{array}$ & $\begin{array}{l}\text { Dead } \\
\text { leaf }\end{array}$ & $\begin{array}{l}\text { Live } \\
\text { stem }\end{array}$ & $\begin{array}{l}\text { Dead } \\
\text { stem }\end{array}$ & $\begin{array}{l}\text { Live } \\
\text { leaf }\end{array}$ & $\begin{array}{l}\text { Dead } \\
\text { leaf }\end{array}$ & $\begin{array}{l}\text { Live } \\
\text { stem }\end{array}$ & $\begin{array}{l}\text { Dead } \\
\text { stem }\end{array}$ & & \\
\hline & $\%$ & $\%$ & $\%$ & $\%$ & $\mathrm{~kg} \mathrm{ha}^{-1}$ & $\mathrm{~kg} \mathrm{ha}^{-1}$ & $\mathrm{~kg} \mathrm{ha}^{-1}$ & $\mathrm{~kg} \mathrm{ha}^{-1}$ & & \\
\hline East & 44.1 & 19.3 & 23.7 & 13.0 & 818 & $448^{a}$ & 471 & $285^{\mathrm{a}}$ & $2020^{\mathrm{a}}$ & 3722 \\
\hline Terrace & 45.9 & 19.2 & 24.1 & 11.1 & 716 & $333^{b}$ & 386 & $193^{b}$ & $1623^{b}$ & 3428 \\
\hline West & 46.3 & 18.4 & 24.5 & 10.8 & 782 & $387^{\mathrm{ab}}$ & 452 & $219^{\mathrm{ab}}$ & $1841^{a b}$ & 3153 \\
\hline
\end{tabular}

Means with the same lower case letter are not significant at $P<0.05$.

Forage CP was greater in the short and medium pastures in August and September of 1992 and for the duration of 1993 (Table 3). Morris et al. (1993) report increased cattle liveweight gain per hectare with increasing pasture height to $8-10 \mathrm{~cm}$ but further increases in pasture height reduced pasture density, forage quality and animal performance. In this study, there were no significant differences $(\mathrm{P}>0.05)$ in crude protein of forage between treatments during the vegetative growth phase in spring when nitrogen levels were fairly high $(>1.3 \%)$. But when the grass began to produce reproductive organs and when nitrogen levels were lower $(<1.3 \%)$, forage crude protein was greater on the shorter pastures $(\mathrm{P}<0.05)$, as hypothesized. the $260 \mathrm{~kg} \mathrm{ha}^{-1}$ recorded by Volesky et al. (1994). Differences in gain per hectare are probably due to the difference in annual precipitation between the 2 locations, viz. $550 \mathrm{~mm}$ vs. $800 \mathrm{~mm}$, and lower soil productive potential at our study site.

Regressions of ADG against vegetation variables produced 6 significant equations (Table 5). The models indicate that management that maximizes the proportion of leaf and live stem while minimizing dead stem, results in the highest animal performance. This concurs with other work on Old Word bluestem which found that digestibility, particularly of stem, declined rapidly with maturity (Forbes and Coleman 1986, Dabo et al. 1987). Under the short grazing treatments of this study, intensive grazing to reduce stem and old tissue also reduced forage on offer

Table 3. The effect of pasture height of Old World bluestem pasture on forage crude protein.

\begin{tabular}{|c|c|c|c|c|c|c|c|c|c|c|c|}
\hline $\begin{array}{l}\text { Pasture } \\
\text { Height }\end{array}$ & 6 May 92 & 10 June 92 & 6 July92 & 24 July92 & 3 Aug 92 & 11 Sep 92 & 23 Oct 92 & 21 May 93 & 18 June 93 & 28 July 93 & $\mathrm{X}$ \\
\hline Short & $10.8 \pm 0.21$ & $7.7 \pm 0.37$ & $9.7 \pm 0.99$ & $9.4 \pm 0.75$ & $10.5 \pm 0.53$ & $8.5 \pm 0.00$ & $3.5 \pm 0.63$ & $8.1 \pm 0.08$ & $7.4 \pm 0.20$ & $5.0 \pm 0.92$ & $8.07 \mathrm{~A}$ \\
\hline Medium & $10.7 \pm 0.67$ & $7.1 \pm 0.92$ & $9.1 \pm 0.60$ & $7.8 \pm 0.71$ & $8.1 \pm 0.41$ & $7.5 \pm 0.55$ & $3.4 \pm 0.03$ & $8.1 \pm 0.17$ & $7.2 \pm 0.31$ & $5.0 \pm 0.11$ & $7.41 \mathrm{~A}$ \\
\hline $\begin{array}{l}\text { Tall } \\
\mathbf{X}\end{array}$ & $\begin{array}{l}10.6 \pm 0.50 \\
10.71 \mathrm{a}\end{array}$ & $\begin{array}{l}7.7 \pm 0.42 \\
7.49 \mathrm{~d}\end{array}$ & $\begin{array}{c}10.5 \pm 2.12 \\
9.77 b\end{array}$ & $\begin{array}{l}7.7 \pm 0.52 \\
8.31 \mathrm{~cd}\end{array}$ & $\begin{array}{l}8.5 \pm 2.53 \\
9.05 b c\end{array}$ & $\begin{array}{l}6.3 \pm 0.24 \\
7.45 \mathrm{~d}\end{array}$ & $\begin{array}{l}3.5 \pm 0.65 \\
3.45 \mathrm{f}\end{array}$ & $\begin{array}{l}7.5 \pm 0.29 \\
7.90 \mathrm{~d}\end{array}$ & $\begin{array}{l}6.9 \pm 0.78 \\
7.18 d\end{array}$ & $\begin{array}{l}4.7 \pm 0.72 \\
4.90 \mathrm{e}\end{array}$ & $7.38 \mathrm{~A}$ \\
\hline
\end{tabular}

Means with the same lower case letter are not significant at $P<0.05$.

Means with the same upper case letter are not significant at $P<0.05$. 
Table 4. Effect of pasture height on steer performance of Old World bluestem pasture grazed at short, medium, and tall grazing heights.

\begin{tabular}{lccc}
\hline Parameter & Short & Medium & Tall \\
Average daily gain $\left(\mathrm{kg} \mathrm{hd}^{-1}\right.$ day $\left.^{-1}\right)$ & $0.64^{\mathrm{b}}$ & $0.69^{\mathrm{ab}}$ & $0.75^{\mathrm{a}}$ \\
Gain per animal $\left(\mathrm{kg} \mathrm{hday}^{-1}\right)$ & $49.8^{\mathrm{b}}$ & $52.1^{\mathrm{ab}}$ & $56.1^{\mathrm{a}}$ \\
Gain per hectare $\left(\mathrm{kg} \mathrm{ha}^{-1}\right)$ & $129.1^{\mathrm{a}}$ & $122.9^{\mathrm{a}}$ & $120.0^{\mathrm{a}}$ \\
\hline
\end{tabular}

Means with the same upper case letter are not significant at $P \propto 0.10$.

sufficiently to reduce animal selection and decrease individual animal performance. The increase in forage quality was too small and for too short a duration to compensate for the reduced availability. Consequently, animal production per hectare was only marginally greater in the shorter pastures.

\section{Root Biomass}

The top $300 \mathrm{~mm}$ of soil contained most (87\%) of root biomass compared to the $300-600 \mathrm{~mm}$ layer $(9 \%$ ) and the $600-900 \mathrm{~mm}$ soil layer (4\%). In 1992, root biomass on all treatments and at all soil depths was less $(P \leq 0.05)$ than in 1993 (Table 6). Both the short and medium height pastures had approximately $70 \%$ the root biomass of the tall pastures $(\mathrm{P} \leq 0.01)$. There was a $16 \%$ difference in the tall pastures between 1992 and 1993. The difference was $34 \%$ and $27 \%$ for the medium and the short treatment pastures between years, respectively. However, these percentages are not entirely comparable since grazing ceased in July 1993.

The WW-Spar root biomass decreased about $30 \%$ during spring growth cycle and did not begin to recover until the last third of the cycle when reproductive tillers were being produced (Coyne and Bradford 1986). In the second half of the growing season, when canopy was regrowing, root biomass declined following the medium and short defoliation treatments. Root biomass increased when growing conditions improved. The results of this study indicate that continuous grazing to maintain very short pasture height has an adverse effect on Old World bluestem root biomass. Maintaining productivity is probably not possible using such intensive grazing. Old World bluestem has exhibited an ability to rapidly recover reserves and root biomass late in the season (Coyne and Bradford 1986). Therefore, with good growing conditions and no grazing late in the season depleted reserves and root mass could recover. However, rains are more variable in fall than in spring, so a late season rest would be only moderately reliable as a means of replenishing root biomass.

Table 5. Regressions of average daily gain (ADG) against standing crop and plant proportions on Old World bluestem pasture grazed at different heights $(n=48)$.

\begin{tabular}{|c|c|c|c|c|}
\hline & & & & $\mathrm{r}^{2}$ \\
\hline (1) & ADG & $=$ & $\begin{array}{l}(2.05 \pm .38)-(.0003 \pm .0002) \\
\text { standing crop }\end{array}$ & 0.0444 \\
\hline (2) & $A D G$ & $=$ & $(.0395 \pm .0026)$ live leaf $\%$ & 0.8327 \\
\hline (3) & $A D G$ & $=$ & $(.0233 \pm .0016)$ live $\%$ & 0.8214 \\
\hline (4) & $\mathrm{ADG}$ & $=$ & $(.0279 \pm .0022)$ total leaf $\%$ & 0.7816 \\
\hline (5) & ADG & $=$ & $\begin{array}{l}(.0248 \pm .0023) \text { live } \%- \\
(.0039 \pm .0042) \text { dead } \%\end{array}$ & 0.8246 \\
\hline (6) & ADG & $=$ & $\begin{array}{l}(.0335 \pm .0050) \text { live leaf } \%+ \\
(.0002 \pm .0106) \text { dead Leaf } \% \\
+(0.114 \pm .0070) \text { live stem } \%- \\
(.0045 \pm .0102) \text { dead stem } \%\end{array}$ & 0.8426 \\
\hline
\end{tabular}

\section{Conclusions}

In both years of this study, forage nitrogen declined significantly from the beginning of May to mid-June (Table 6). Nitrogen fertilizer levels in this study were moderately low $\left(112 \mathrm{~kg} \mathrm{ha}^{-1}\right.$ of $\mathrm{N})$ and nitrogen was, therefore, probably moderately limiting for the duration. Taliaferro et al. (1975) obtained positive increases in yield following $67<135<269 \mathrm{~kg} \mathrm{ha}^{-1}$ of $\mathrm{N}$ fertilizer. Greater levels of nitrogen would increase photosynthetic efficiency per unit leaf area and maintain a more constant growth rate (Coyne and Bradford 1987). This would also probably improve and hasten energy reserve and root biomass recovery in the latter half of early and late regrowth cycles (Coyne and Bradford 1986) and increase forage quality for most of the growing season.

Table 6. Root carbon mass $\left(x 1000=\mathrm{g} \mathrm{m}^{-2}\right)$ of Old World bluestem at 3 soil depths under short, medium, and tall grazing heights.

\begin{tabular}{lcccc}
\hline Pasture Height & $\begin{array}{c}\text { Topsoil } \\
(0-100 \mathrm{~mm})\end{array}$ & $\begin{array}{c}\text { Midsoil } \\
(100-200 \mathrm{~mm})\end{array}$ & $\begin{array}{c}\text { Bottom Soil } \\
(200-400 \mathrm{~mm})\end{array}$ & Total \\
\hline Short & $0.549 \mathrm{~b}$ & 0.048 & 0.021 & $0.618 \mathrm{~b}$ \\
Medium & $0.492 \mathrm{ab}$ & 0.062 & 0.027 & $0.581 \mathrm{~b}$ \\
Tall & $0.726 \mathrm{a}$ & 0.076 & 0.041 & $0.843 \mathrm{a}$ \\
$\overline{\mathrm{X}}$ & 0.590 & 0.062 & 0.030 & \\
1992 & 0.518 & 0.041 & 0.025 & $0.584 \mathrm{~B}$ \\
1993 & 0.660 & 0.083 & 0.034 & $0.777 \mathrm{~A}$ \\
\hline
\end{tabular}

Means with the same lower case letter are not significant at $\mathrm{P}<0.05$.

Means with the same upper case letter are not significant at $P<0.05$.

Continuous variable stocking has been shown to overcome the inefficiencies of set stocking (Johnson and Parsons 1985). When moisture or fertility are not limiting, pastures maintained at a relatively low leaf area index using continuous variable stocking produced less reproductive tissue than pastures kept at greater leaf area index. In these circumstances, greatest animal production was associated with treatments that had lower leaf area index and plant productivity (Grant et al. 1983; Parsons et al. 1983).

In this study, where both moisture and nutrients were limiting, Old World bluestem displayed the same response but of lesser magnitude. Grazing intensively increased the proportion of live and dead leaf in the pasture. Animal performance per hectare was only marginally greater in the medium and short pasture treatments. It is possible that with a greater range in forage allowance a greater difference would have been obtained regarding the proportion of leaf, quality of forage and animal performance per hectare with increasing forage allowance. Continuous variable stocking as practiced in this study would usually be impractical under commercial grazing circumstances. The same effect can be achieved by using temporary fencing to adjust the grazeable area and cutting the balance for hay.

Forage crude protein did not differ between treatments during the vegetative growth phase in spring when forage nitrogen levels were relatively high. When the grass began to produce reproductive organs and when forage nitrogen levels were lower, forage crude protein was greater on the shorter pastures. By splitting fertilizer applications, as in this study, forage growth, forage quality and root and energy reserve replenishment could be significantly enhanced. Such management may allow pastures to be grazed less intensively to achieve efficient and profitable production that 
is sustainable from year to year. Volesky (1994) and Volesky et al. (1994) demonstrate that rotational stocking increases utilization and production efficiency and may provide a means of maintaining root biomass, a high proportion of live leaf and utilization efficiency. To improve the utilization and productive efficiency of Old World bluestem pastures, it will be necessary to investigate combining rotational stocking and better soil fertility management while identifying how these plants respond physiologically to such treatments.

\section{Literature Cited}

Association of Analytical Chemists (A.O.A.C.). 1990. Official methods of analysis (15th ed.). Association of Analytical Chemists, Washington D.C.

Blazer, R.E., R.C. Hammes, J.P. Fontenot, H.T. Bryant, C.E. Polan, D.D. Wolf, F.S. McClaugherty, R.G. Kline, and J.S. Moore. 1986. Forage-Animal Management Systems, Virginia Polytechnic Institute and state University, Blacksburg, Virg.

Bransby, D.I., A.G. Matches, and G.F. Krause. 1977. Disc meter for rapid estimation of herbage yield in grazing trials. Agron. J. 69:393-396.

Coyne, P.I. and J.A. Bradford. 1984. Leaf gas exchange in 'Caucasian' bluestem in relation to light, temperature, humidity and $\mathrm{CO}_{2}$. Agron. $\mathrm{J}$. 76:107-113.

Coyne, P.I. and J.A. Bradford. 1985. Some growth characteristics of four old world bluestems. J.Range Manage. 38:27-32.

Coyne, P.I. and J.A. Bradford. 1986. Biomass partitioning in 'Caucasian' and 'WW-Spar' old world bluestems. J.Range Manage. 39:303-310.

Coyne, P.I. and J.A. Bradford. 1987. Nitrogen and carbohydrate partitioning in 'Caucasian' and 'WW-Spar' old world bluestems. J.Range Manage. 40:353-360.

Dabo, S.M., C.M. Taliaferro, S.W. Coleman, F.P. Horn, and P.L. Claypool. 1987. Yield and digestibility of old world bluestem grasses as affected by cultivar, plant part and maturity. J.Range Manage. 40:10-15.

Dewald, C.L., W.L. Berg, and K. Khaleeluddin. 1985. Old world bluestem cultivar selection for Oklahoma. In: Proc. of a conference on old world bluestems in the Southern Great Plains. Clinton, Okla.

Eck, H.V. and P.L. Sims. 1984. Grass species adaptability in the Southern High Plains - 36-year assessment. J. Range Manage. 37:211-217.

Forbes, T.D.A. and S.W. Coleman. 1986. Herbage intake and ingestive behaviuor of grazing cattle as influenced by variation in sward characteristics. In: F.P Horn et al. (eds.), Grazinglands research at the plant animal interface, Winrock Int, Morrilton, Ark. p 141-152.

Grant, S.A., G.T. Barthram, L. Torvell, J. King, and K. Smith. 1983. Sward management, lamina turnover and tiller population density in continuously stocked Lolium perenne dominated swards. Grass and Forage sci. 38:333-344.

Johnson, I.R. and A.J. Parsons. 1985. Use of a model to analyse the effects of continuous grazing managements on seasonal patterns of grass production. Grass and Forage Sci. 40:449-458.

Maxwell, T.J. and T.T. Treacher. 1986. Decision rules for grassland management. In: G.E. Pollott (ed.) Efficient Sheep Production from grass. British Grassland Society, Institute of Grassland and Animal Production, Berkshire, England.

McNaughton, S.J. 1979. Grazing as an optimization process: grassungulate relationships in the Serengeti. American Naturalist. 113: 691-703.

Morris, S.T., S.W. Hirschberg, A. Michel, W.J. Parker, and S.N. McCutcheon. 1993. Herbage intake and liveweight gain of bulls and steers continuously stocked at fixed sward heights during autumn and spring. Grass and Forage Sci. 48:109-117.
Murphy, B. 1990. Pasture Management. In: C.A. Francis, C.B. Butler and L.D. King (eds.). Sustainable Agriculture in Temperate Zones. Wiley-Interscience, N.Y.

Parsons, A.J., I.R. Johnson, and A. Harvey. 1988. Use of a model to optimize the interaction between frequency and severity of intermittent defoliation and to provide a fundamental comparison of the continuous and intermittent defoliation of grass. Grass and Forage Sci. 43:49-59.

Parsons, A.J., E.L. Leafe, B. Collett, P.D. Penning, and J. Lewis. 1983. The physiology of grass growth under grazing. II. Photosynthesis, crop growth and animal intake of continuously grazed swards. J. Appl. Ecol. 20:127-139.

Sims, P.L. and C.L. Dewald. 1982. Old world bluestems and their forage potential for the Southern Great Plains. USDA Agr. Res. Serv., Agr. Reviews and manuals ARM-S-28.

Sims, P.L., C.L. Dewald, and S. Cowles. 1983. Advancements with old world bluestems. p. 4-11. In: Proc. Range and Pasture Seeding in the Southern Great Plains, Texas A\&M Univ. Agr. Res. and Ext. Ctr., Vernon, Tex.

Smucker, A.J.M., S.L. McBurney, and A.K. Srivastava. 1982. Quantitative separation of roots from compacted soil profiles by the hydropneumatic elutriation system. Agron. J. 74:500-504.

Statistical Analysis System (SAS). 1985. SAS User's Guide. SAS Institute Inc., Cary, N. C.

Steel, R.G.D. and J.H. Torrie. 1960. Principles and procedures of statistics. McGraw-Hill, N.Y.

Taliaferro, C.M., F.P. Horn, B.B. Tucker, R. Totusek and R.D. Morrison. 1975. Performance of three warm-season perennial grasses and a native range mixture as influenced by $N$ and $P$ fertilization. Agron. J. 67:289-292.

Volesky, J.D. 1994. Tiller defoliation of frontal, continuous and rotational grazing systems. J. Range Manage. 47:215-219.

Volesky, J.D., F.De Achaval O'Farrell, W.C. Ellis, M.M. Kothmann, F.P. Horn, W.A. Phillips, and S.W. Coleman. 1994. A comparison of frontal, continuous and rotational grazing systems. J. Range Manage. 47:210-214. 